\title{
ON SERUM PROTEIN COMPONENTS OF MURINE LEPROSY
}

\author{
Shinii Nishimura and Kono Michiyuki \\ Department of Dermatology, Osaka University Medical School
}

\begin{abstract}
Serum protein components were examined with electrophoresis with 28 rats of serious, slight, unrevealedly infected and intact cases. The results showed that in both serious and slight cases of murine leprosy $\alpha$-globulin and albumin level did not differ from those in intact rats. In each case, the size of leproma was not in proportion with $\alpha$-globulin amount. Some differences were recognized among the results of measurement, but they were of no value from the statistical view.

These results enable us to understand that human and murine leprosy are quite different from each other in serum protein components, and supply us a standpoint for the study on $\alpha$-globulin increase in lepra tuberosa.
\end{abstract}

\section{鼠癩の血淸蛋白組成について}

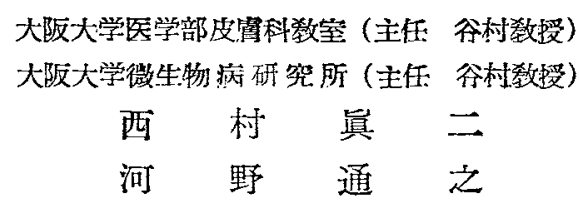

\footnotetext{
緸 言

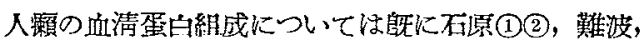
藤原(4)，故口(3)等多数の墊告が变り，我等の一人河里も

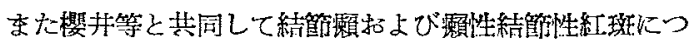

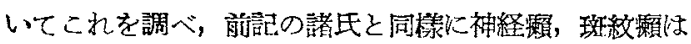

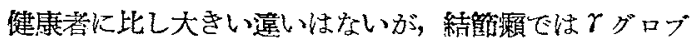
リンの罣加はることを認めている。一方鼠制の血清蛋白 組成については最近重松，中村(5)等か健康白鼠祅よび接

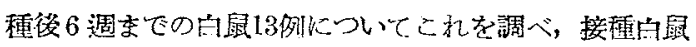
はアルブミン，グロプリソ垬に健康曰鼠に比し著しい差 を認めないが，た心゙ケグロブリンのみは稍々減少の倾向 を示したと報じているに瀜ざない。

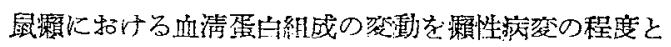

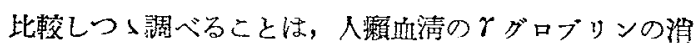
長を考察する上执いて一つの筫料を提供するるのであ

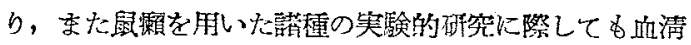
生化学の立場为ら有力なる示唆汃期待し得られる。出上

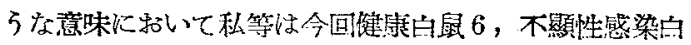

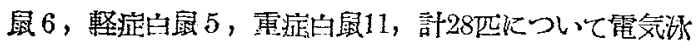

動裝置による弗験を行つたので，以下その成績を啹告し ようと思う。

\section{實 驗 材 料}

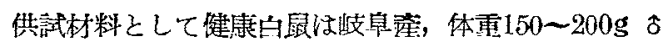

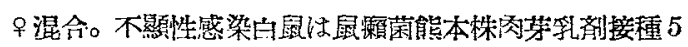
ク月にして不發症のもの，体重150２00g 合守混合。軽

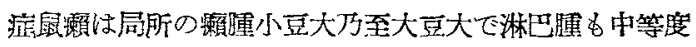

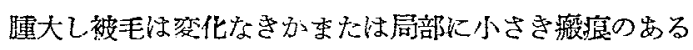

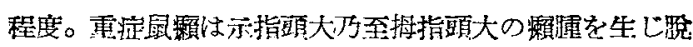

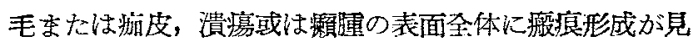
られ淋巴腺は著しく睡大硬化したものである。体重は重

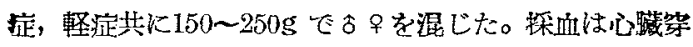

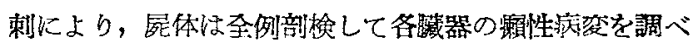
ると共に，脯炎，寄生虫症等を㑇めたものはこれを除外 した。

\section{裝置及方法}

日立製作所のH T一A型を使用, 透析法電気泳動研究 
会規定に従つて行い，泳動条件と乙て水溫 $20^{\circ} \mathrm{C}$ 以下の

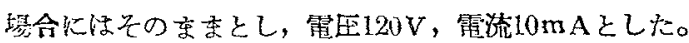

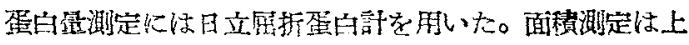

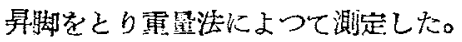

\section{實 驗 成 績}

其 1 ）健康白鼠の血清蛋白組成：先ず対照として健康

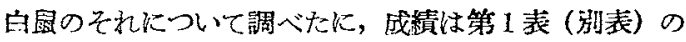
通りであつた。

即ちアルブミン䛧は平均 $2.97 \mathrm{~g} / \mathrm{d} 1(50.9 \%)$ に，rグ ロプリンは平均 $1.23 \mathrm{~g} / \mathrm{dl}(21.2 \%)$ を示した。これを各 例について見ると

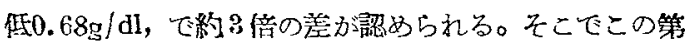

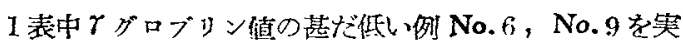
験手技の誤による犆として，これを計算より除外してよ いかとらかを㶳式によつて梌討すると，

$$
\begin{array}{ll}
\overline{\mathrm{X}}=-\frac{1}{n} \sum_{\mathrm{i}=1}^{n} \mathrm{Xi}_{\mathrm{i}} & \mathrm{S}^{2}=\sum_{\mathrm{i}=1}^{\mathrm{n}}(\mathrm{Xi}-\overline{\mathrm{X}})^{2} \\
\overline{\mathrm{X}}=\frac{1}{\mathrm{n}-2} \sum_{\mathrm{i}=3}^{n} \mathrm{Xi}_{\mathrm{i}} & \mathrm{S}_{1 \cdot 2}^{2}=\sum_{1=3}^{n}\left(\mathrm{Xi}-\overline{\mathrm{X}}_{1 \cdot 2}\right)^{2} \\
\mathrm{~S}_{1.2}^{2} / \mathrm{S}^{2}<0.0565 \text { ならば寨却しても差支えないこと }
\end{array}
$$
Кなる。今第 1 蒜より

$$
\begin{aligned}
& \overline{\mathrm{X}}= \frac{1}{6}(2.01+1.21+0.68+1.2+1.01+132=1.23 \\
& \mathrm{S}^{2}= \sum_{\mathrm{i}=1}^{\mathrm{n}}(\mathrm{Xi}-\overline{\mathrm{X}})^{2}=(2.01-1.23)^{2}+(1.21-1.23)^{2} \\
&+(0.68-1.23)^{2}+(1.2-1.23)^{2}+(1.01-1.23 \\
&)^{2}+(1.32-1.23)^{2}=0.9687 \\
& \overline{\mathrm{X}}_{1.2}= \frac{1}{4}(2.01+1.21+1.2+1.32)=1.435 \\
& \mathrm{~S}_{1.2}^{2}=\mathrm{\Sigma}_{i=3}^{\mathrm{n}}(\mathrm{Xi}-\overline{\mathrm{X}})^{2}=(2.01-1.435)^{2}+(1.21-1.4 \\
&\quad 85)^{2}+(1.2-1.435)^{2}+(1.32-1.435)^{2}=0.4497 \\
& \frac{\mathrm{S}_{1.2}^{2}}{\mathrm{~S}^{2}}=\frac{0.4497}{0.9687}=0.494
\end{aligned}
$$

即亏 0.0565 より $\frac{\mathrm{S}_{\mathrm{L} \cdot 2}^{2}}{\mathrm{~S}^{2}}$ が大なり应例 $6 ， 9$ の 2 例 を査却するならば5\%以上の佁険をとるならことになる

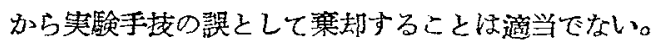

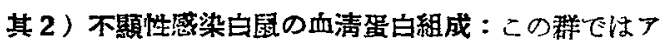

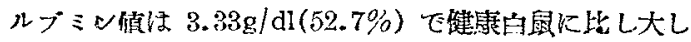

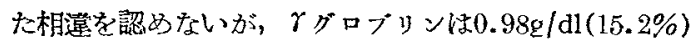

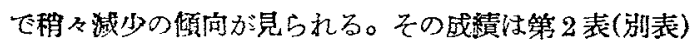
の通りである。

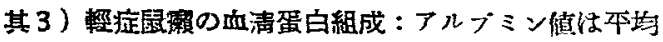
$2.99 \mathrm{~g} / \mathrm{dl}(45.8 \%), \gamma$ グロブリン值深平均 $\mathrm{l} .2 \mathrm{lg} / \mathrm{dl}(18$.
7\%) を示しこなで终煡康兒鼠比しアルブミン，ケグロ

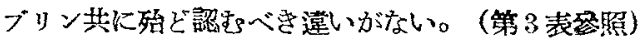

其 4) 重症鼠瀨の血清蛋白組成:この群でアルブミ

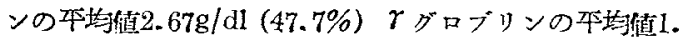
$16 \mathrm{~g} / \mathrm{dI}(18.8 \%)$ で煡康白鼠に比し雨者共に稍乃诚退し ている。更に第2，3表についてアルブミンととグロブ

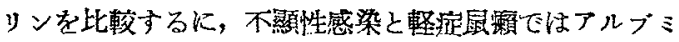

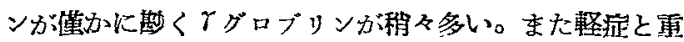

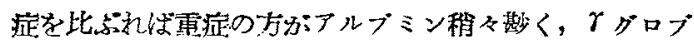
リンも僅か记勘いがその百分此では殆ど空りがない。 （第4 表答照）

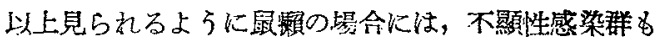

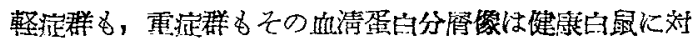
して特異相を現わさず。

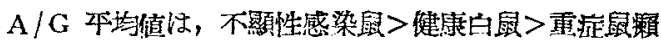

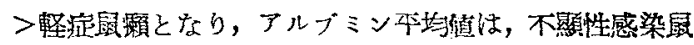

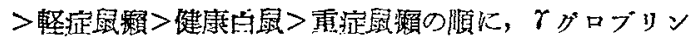

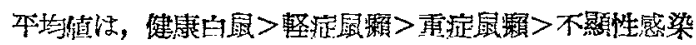

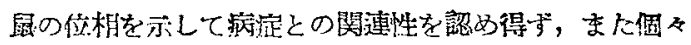

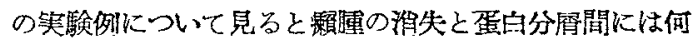
等の関保をる見出すことが出来なかつた。

\section{測定值の計數學的考察}

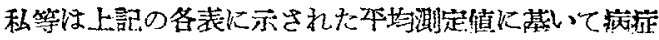
例の各群間に著いい差のないことを，一応述べたのであ るが，然しながら事笑として，たと六僅少にもせよ差は

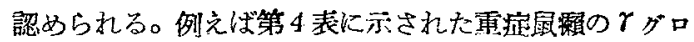

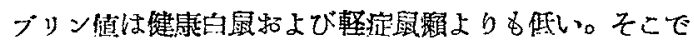

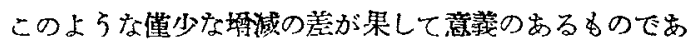
ろかどらかにつ、計数学的に

$\frac{(\bar{X}-\bar{U})^{2}}{W^{2}}\left(\frac{M N}{M+N}\right)$ の式によつて差の继の湌定を行つて みることにした。

第1表より $\overline{\mathrm{X}_{1}}=\frac{1}{6}(2.01+0.68+1.21+1.01+1.2+$

$$
1.32)=1.23
$$

$$
\begin{aligned}
& \mathrm{U}_{1}^{2}=\frac{1}{6-1}\left(2.01^{2}+0.68^{2}+1.21^{2}+1.01^{2}+1.2^{2}+1.32^{2}\right. \\
& \left.-1.23^{2} \times 6\right)=(10.1691-9.0774) \frac{1}{5}=1.0917 \times \frac{1}{5}= \\
& 0.21834
\end{aligned}
$$

第2表より $\overline{\mathrm{Y}}_{1}=\frac{1}{6}(0.83+0.64+0.55+0.91+1.1+$

$$
1.87)=0.98
$$

$\mathrm{U}_{2}^{2}=\frac{1}{6-1}\left(0.83^{2}+0.64^{2}+0.55^{2}+0.91^{2}+1.1^{2}+1.87^{2}\right.$

$\left.-0.98^{2} \times 6\right)=\frac{1}{5}(6.936-5.7624)=1.1736 \times \frac{1}{5}=0.2847$ 
第3表より ${\overline{Y_{2}}}_{2}=\frac{1}{5}(1.10+0.79+1.5+1.32+1.35)=$ 1. 21

$$
\begin{gathered}
U_{3}^{2}=\frac{1}{5-1}\left(1.1^{2}+0.79^{2}+1.5^{2}+1.32^{2}+1.85^{2}-1.21^{2}\right. \\
\times 5)=\frac{1}{4}(7.649-7.3205)=0.3285 \times \frac{1}{4}=0.0821
\end{gathered}
$$

第 4 表より $\quad \overline{\mathrm{Y}}_{3}=\frac{1}{11}(1.16+1.11+0.72+0.9+1.67+1$. $72+1.06+0.77+1.21+0.95+1.44)=1.16$ $\mathrm{U}_{4}^{2}=\left(1.16^{2}+1.11^{2}+0.72^{2}+0.9^{2}+1.67^{2}+1.72^{2}+\right.$ $\left.1.06^{2}+0.77^{2}+1.21^{2}+0.95^{2}+1.44^{2}-1.16^{2} \times 11\right)$ $=\frac{1}{10}(15.8101-14.8016)=1.0085 \times \frac{1}{10}=0.10085$ $F_{1}=\frac{\left(\bar{X}_{1}-\bar{Y}_{1}\right)^{2}}{W^{2}}\left(\frac{M N}{M+N}\right)=\frac{(1.23-0.98)^{2}}{0.22653} \times \frac{36}{12}=$ $\frac{0.0625 \times 36}{0.22653 \times 12}=0.823$ $W^{2}=\frac{\Sigma^{M}\left(X_{i}-\bar{X}\right)^{2}+\Sigma^{N}\left(Y_{i}-\bar{Y}\right)^{2}}{M+N-2}=\frac{1.0917+1.1736}{6+6-2}=$ $\frac{2.2653}{10}=0.22653$ $\mathrm{n}_{1}=1 \quad \mathrm{n}_{2}=\mathrm{M}+\mathrm{N}-2=10 \quad \mathrm{~F}$-分布の表厄 $\mathrm{F}=4.96$ $F_{2}=\frac{\left(\overline{X_{1}}-\overline{Y_{2}}\right)^{2}}{W_{1}^{2}}\left(\frac{M N}{M+N}\right)=\frac{(1.23-1.21)^{2}}{0.1578} \times \frac{30}{11}=$ $\frac{0.0004 \times 30}{0.1578 \times 11}=0.0068$ $w_{1}^{2}=\frac{1.0917+0.3285}{6+5-2}=\frac{1.4202}{9}=0.1578$ $\mathrm{n}_{1}=1 \quad \mathrm{n}_{2}=\mathrm{M}+\mathrm{N}-2=9 \quad \mathrm{~F}$-分布の黄て $\mathrm{F}=5.12$ $F_{3}=\frac{\left(\bar{X}_{1}-\overline{Y_{3}}\right)^{2}}{W_{2}^{2}}\left(\frac{M N}{M+N}\right)=\frac{(1.23-1.16)^{2}}{0.140013} \times \frac{66}{17}=$ $\frac{0.0049 \times 66}{0.140013 \times 17}=0.13$ $w_{2}^{2}=\frac{1.0917+1.0085}{6+11-2}=\frac{2.1002}{15}=0.140013$ $\mathrm{n}_{1}=1 \quad \mathrm{n}_{2}=\mathrm{M}+\mathrm{N}-2=15 \mathrm{~F}$-分存の表厄 $\mathrm{F}=4.54$ 以上の計算によつて得た $F_{0}$ の値は何れる $F$-分布の

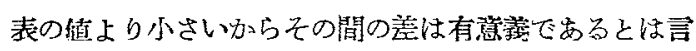
い得ない。即ちこれによつても各群間に特異相のないこ とが明かになつた。

\section{考按}

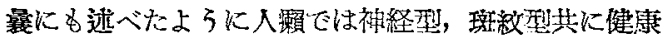

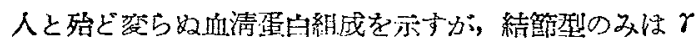
グロブリンが著明に墰加している。しかるに鼠獺とは車 绽例に㧊いてさえ健康白鼠との間に劃然たる相違が現わ れて来ない。かよらな事笑は一見期待に反した結果とも 見えるが，これを梁く考察すると，もとると人顧と鼠観 の本望的な相異に起因するすのとして兩者の異同を追究 する上に一つの新知見を加えたことになり，また一面結

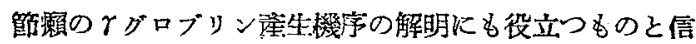

ずる。

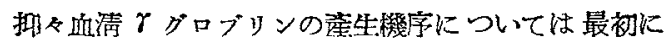
Ehrich (6) Dougherty (7) 等が淋巴球が抗体万侄グロブ

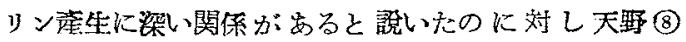

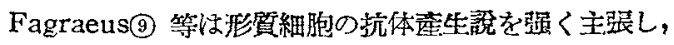

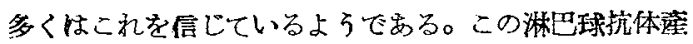

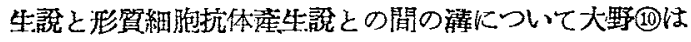
次のような說明を与交た。即号淋巴球の死隇から热清中 にチモ核酸がもたらされ，この低分子手も核酸は形買細

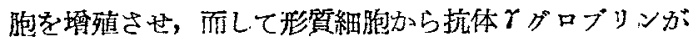
锤生されるものであると言らのである。さて大野氐のこ

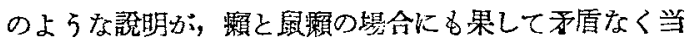

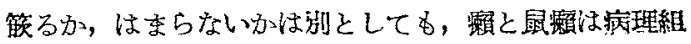
織学的にかなり著明な相珙が㤁つて，その一つとして顀

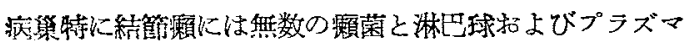

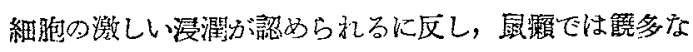

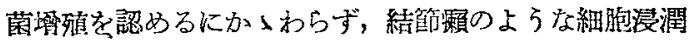
は極めて軽微厄，殆ど炎性反应を伴わない特有の肉考霄

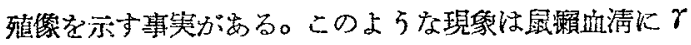
グロプリンの壖量を認めない我等の军験成縝亡併せて，

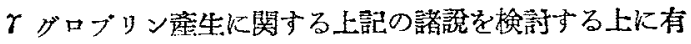
力なる示㥖を与えるすのてはないだろろか。

\section{結論}

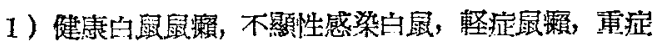

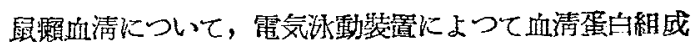
を調べた。

2）鼠制尚鼠各咨験群のアルブミンおよびグロブリン

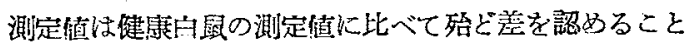
が来な来なつた。

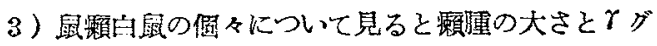
ロブリンとは全く関係がなかつた。

4)各群間の測定㨁の谨少な美異を計数学的に一定の 等式に优つて再换討したが，第 1 表乃至第 4 表に現われ た杵造澺義のないるのであることが明かになつた。

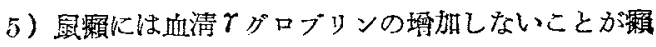
との相異点の一つをあることを知つた。

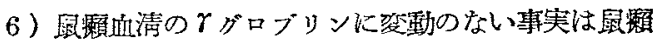
病嶣に常に無数の菌を證明するにもかいわらず，炎性反

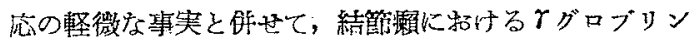

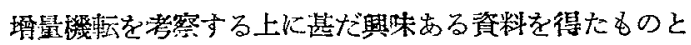
信ずる。

(测定徝の計数学的考察については本学理学部小川潤

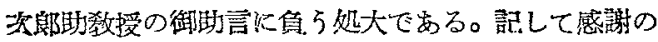
意を萧す)

(この研究は科学研究費に賁ら処大である。谷村) 


\section{主 要 文 献}
1) 石原 レプラ誌 $5,19,1950$
2) 石原 レプラ菬 $6,19,1950$
3 ) 坂ロ レプラ蒜 $2,20,1951$.

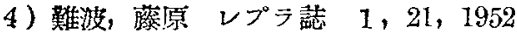
5）雷松，中村 レプラ㺊 $6 ， 20$

6) Ehrich, W, E and Harris, T. N: J. Exp. Med $76,335,1942$

7) Dlougherty : T. E, Chase, J, H, and White A : Pros soc. Exp. Biol. 57, 295, 1944

8) 天野 日面会被 $25,9,1946$

9) A, Fagraeus : J.Immunology 58, 1.948

10) 大野 日䉼医学 $11,38,1951$

第1表

健康白鼠の血清蛋白組成

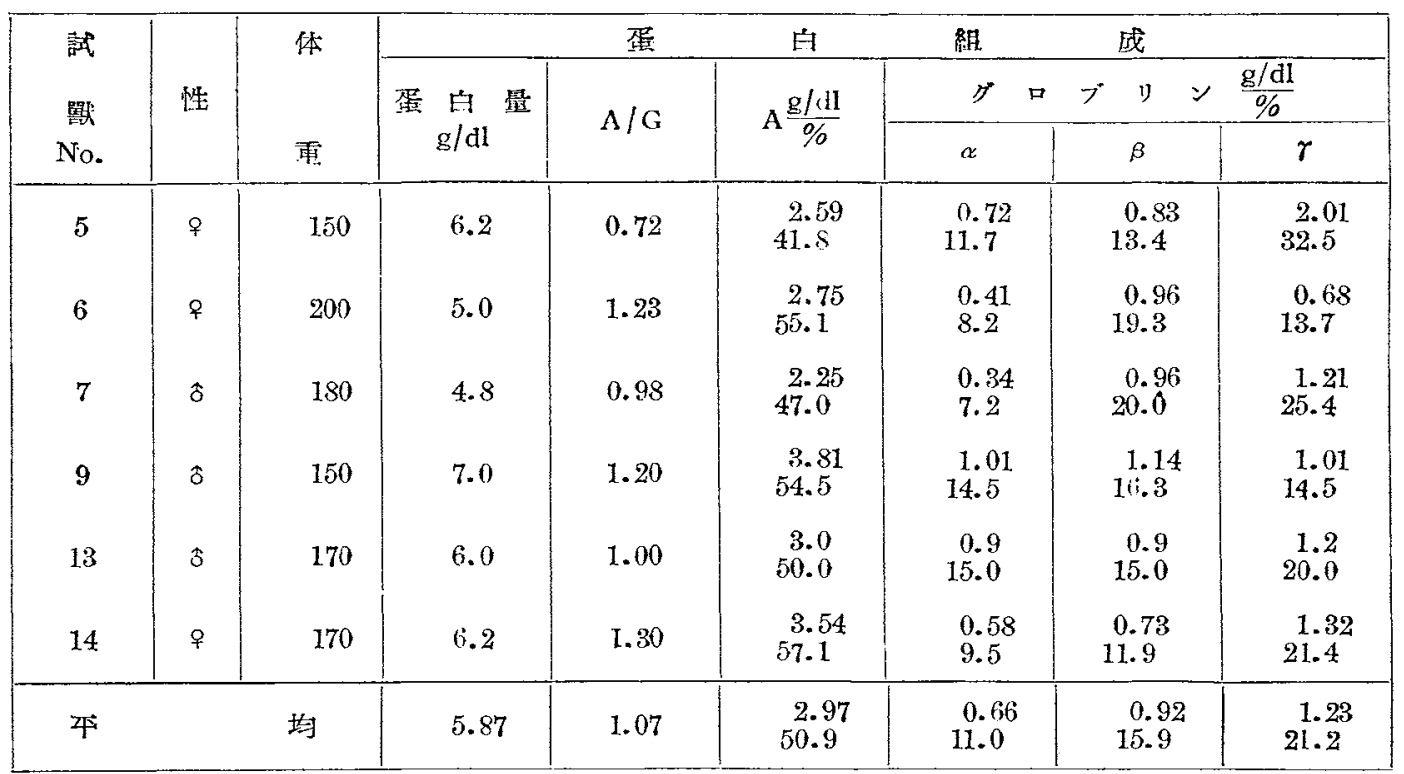

第 2 表

不顯焳感染白鼠の血清蛋白組成

\begin{tabular}{|c|c|c|c|c|c|c|c|c|c|c|c|c|c|c|c|}
\hline \multirow{3}{*}{$\begin{array}{l}\text { 獸 } \\
\text { No. }\end{array}$} & \multirow{3}{*}{ 性 } & \multirow{3}{*}{$\begin{array}{l}\text { 体 } \\
\text { 重 }\end{array}$} & \multirow{3}{*}{$\begin{array}{l}\text { 接 } \\
\text { 種 } \\
\text { 緅 } \\
\text { 渦 }\end{array}$} & \multicolumn{3}{|c|}{ 剖 } & \multicolumn{3}{|c|}{ 検 } & \multicolumn{2}{|c|}{ 蛋 } & 白 & \multicolumn{3}{|c|}{ 战 } \\
\hline & & & & \multirow{2}{*}{$\begin{array}{l}\text { 曊 } \\
\text { 腫 }\end{array}$} & \multirow{2}{*}{$\begin{array}{l}\text { 鼠 } \\
\text { 蹊 } \\
\text { 腺 }\end{array}$} & \multirow{2}{*}{$\begin{array}{l}\text { 腋 } \\
\text { 霄 } \\
\text { 滕 }\end{array}$} & \multirow[t]{2}{*}{ 瞋 } & \multirow[t]{2}{*}{ BF } & \multirow[t]{2}{*}{ 脾 } & \multirow{2}{*}{$\begin{array}{c}\text { 蛋白量 } \\
\text { g/dl }\end{array}$} & \multirow[t]{2}{*}{$\mathrm{A} / \mathrm{G}$} & \multirow{2}{*}{$\mathrm{A} \frac{\mathrm{g} / \mathrm{dl}}{\%}$} & \multicolumn{3}{|c|}{ グロプリシ $\frac{\mathrm{g} / \mathrm{dl}}{\%}$} \\
\hline & & & & & & & & & & & & & $\alpha$ & $\beta$ & $\gamma$ \\
\hline 17 & 9 & 130 & 7 月 & - & - & - & - & - & - & 5.0 & 1.00 & $\begin{array}{r}2.5 \\
50.0\end{array}$ & $\begin{array}{l}0.69 \\
13.8\end{array}$ & $\begin{array}{l}0.97 \\
19.4\end{array}$ & $\begin{array}{l}0.83 \\
16.6\end{array}$ \\
\hline 25 & $q$ & 150 & 10月 & - & + & - & - & - & - & 6.0 & 1.09 & $\begin{array}{c}3.12 \\
52.0\end{array}$ & $\begin{array}{c}0.98 \\
13.0\end{array}$ & $\begin{array}{r}1.43 \\
23.9\end{array}$ & $\begin{array}{c}0.64 \\
10.8\end{array}$ \\
\hline 28 & 우 & 140 & 10月 & - & - & - & - & - & - & 5.8 & 1.17 & $\begin{array}{l}3.12 \\
53.8\end{array}$ & $\begin{array}{c}0.98 \\
17.0\end{array}$ & $\begin{array}{l}1.06 \\
18.4\end{array}$ & $\begin{array}{l}0.55 \\
9.5\end{array}$ \\
\hline 1 & $q$ & 150 & 6 月 & - & - & - & - & - & - & 7.0 & 1.30 & $\begin{array}{l}3.95 \\
56.5\end{array}$ & $\begin{array}{l}0.91 \\
13.0\end{array}$ & $\begin{array}{l}1.21 \\
17.3\end{array}$ & $\begin{array}{l}0.91 \\
13.0\end{array}$ \\
\hline 2 & $\hat{\delta}$ & 250 & 6 月 & - & - & - & - & - & - & 6.4 & 1.10 & $\begin{array}{l}3.44 \\
53.8\end{array}$ & $\begin{array}{l}0.58 \\
9.2\end{array}$ & $\begin{array}{l}1.22 \\
19.2\end{array}$ & $\begin{array}{l}1.10 \\
17.3\end{array}$ \\
\hline 4 & $\hat{s}$ & 180 & 6 月 & - & - & - & - & - & - & 7.8 & 1.00 & $\begin{array}{r}3.9 \\
50.0\end{array}$ & $\begin{array}{c}0.78 \\
10.0\end{array}$ & $\begin{array}{c}1.24 \\
16.0\end{array}$ & $\begin{array}{r}1.87 \\
24.0\end{array}$ \\
\hline & & & 均 & & & & & & & 6.3 & 1.11 & $\begin{array}{c}3.38 \\
52.7\end{array}$ & $\begin{array}{r}0.78 \\
12.7\end{array}$ & $\begin{array}{c}1.18 \\
19.0\end{array}$ & $\begin{array}{c}0.98 \\
15.2\end{array}$ \\
\hline
\end{tabular}


第3表

軽症鼠瀨の血清蛋白組成

\begin{tabular}{|c|c|c|c|c|c|c|c|c|c|c|c|c|c|c|c|}
\hline \multirow{3}{*}{$\begin{array}{l}\text { 試 } \\
\text { 獸 } \\
\text { No. }\end{array}$} & \multirow{3}{*}{ 性 } & \multirow{3}{*}{$\begin{array}{l}\text { 体 } \\
\text { 重 }\end{array}$} & \multirow{3}{*}{ 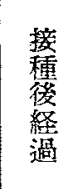 } & \multicolumn{3}{|c|}{ 剖 } & \multicolumn{3}{|c|}{ 㛟 } & \multicolumn{3}{|c|}{ 蛋 } & \multicolumn{3}{|c|}{ 成 } \\
\hline & & & & \multirow{2}{*}{$\begin{array}{c}\text { 䨳理 } \\
\mathbf{g}\end{array}$} & \multirow{2}{*}{$\begin{array}{l}\text { 鼠 } \\
\text { 蹊 } \\
\text { 腺 }\end{array}$} & \multirow{2}{*}{$\begin{array}{l}\text { 腋 } \\
\text { 窝 } \\
\text { 腺 }\end{array}$} & \multirow{2}{*}{ 肺 } & \multirow{2}{*}{ 塛 } & \multirow[t]{2}{*}{ 脾 } & \multirow{2}{*}{$\begin{array}{l}\text { 蛋的昌 } \\
\mathrm{g} / \mathrm{dl}\end{array}$} & \multirow{2}{*}{$\mathrm{A} / \mathrm{G}$} & \multirow{2}{*}{$\mathrm{A} \frac{\mathrm{g} / \mathrm{dl}}{\%}$} & \multicolumn{3}{|c|}{ グロブリン $\frac{\mathrm{g} / \mathrm{dl}}{\%}$} \\
\hline & & & & & & & & & & & & & $\alpha$ & $\beta$ & $\gamma$ \\
\hline 19 & $\delta$ & 170 & 7 月 & 0.1 & H & + & - & - & - & 6.8 & 1.1 & $\begin{array}{c}3.67 . \\
54.0\end{array}$ & $\begin{array}{c}0.91 \\
13.5\end{array}$ & $\begin{array}{c}1.10 \\
16.2\end{array}$ & $\begin{array}{c}1.10 \\
16.2\end{array}$ \\
\hline 26 & $\hat{o}$ & 160 & 10 月 & 0.1 & $\perp$ & H & - & - & - & 6.0 & 0.78 & $\begin{array}{l}2.64 \\
44.0\end{array}$ & $\begin{array}{l}1.11 \\
18.5\end{array}$ & $\begin{array}{c}1.44 \\
24.0\end{array}$ & $\begin{array}{c}0.79 \\
13.3\end{array}$ \\
\hline 30 & $\hat{\delta}$ & 150 & 10 月 & 0.2 & + & + & - & - & - & 6.0 & $0.7 \delta$ & $\begin{array}{c}2.56 \\
42.8\end{array}$ & $\begin{array}{c}0.75 \\
12.5\end{array}$ & $\begin{array}{c}1.17 \\
19.5\end{array}$ & $\begin{array}{c}1.50 \\
25.0\end{array}$ \\
\hline 48 & $\hat{o}$ & 150 & 10 月 & 0.1 & + & + & - & - & - & 6.8 & 0.78 & $\begin{array}{c}2.98 \\
43.9\end{array}$ & $\begin{array}{c}0.82 \\
12.1\end{array}$ & $\begin{array}{c}1.65 \\
24.3\end{array}$ & $\begin{array}{c}1.32 \\
19.5\end{array}$ \\
\hline 47 & q & 180 & 10 月 & 0.2 & + & \# & - & - & - & 7.0 & 0.8 & $\begin{array}{l}3.10 \\
44.4\end{array}$ & $\begin{array}{c}1.16 \\
16.6\end{array}$ & $\begin{array}{c}1.35 \\
19.4\end{array}$ & $\begin{array}{c}1.35 \\
19.4\end{array}$ \\
\hline 4 & & & 均 & & & & & & & 6.5 & 0.84 & $\begin{array}{c}2.99 \\
45.8\end{array}$ & $\begin{array}{c}0.95 \\
14.6\end{array}$ & $\begin{array}{c}1.34 \\
20.6\end{array}$ & $\begin{array}{c}1.21 \\
18.7\end{array}$ \\
\hline
\end{tabular}

第 4 表

重症鼠瀨の䘏清蛋白繳成

\begin{tabular}{|c|c|c|c|c|c|c|c|c|c|c|c|c|c|c|c|}
\hline \multirow{3}{*}{$\begin{array}{l}\text { 試 } \\
\text { 獸 } \\
\text { No. }\end{array}$} & \multirow{3}{*}{ 性 } & \multirow{3}{*}{$\begin{array}{l}\text { 体 } \\
\text { 䨘 }\end{array}$} & \multirow{3}{*}{ 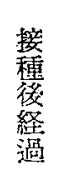 } & \multicolumn{3}{|c|}{ 韵 } & \multicolumn{3}{|c|}{ 㭲 } & \multicolumn{3}{|c|}{ 蛋 } & \multicolumn{3}{|c|}{ 成 } \\
\hline & & & & \multirow{2}{*}{$\begin{array}{c}\text { 䠝輁 } \\
\mathrm{g}\end{array}$} & \multirow{2}{*}{$\begin{array}{l}\text { 鼠 } \\
\text { 踩 } \\
\text { 䠌 }\end{array}$} & \multirow{2}{*}{$\begin{array}{l}\text { 腋 } \\
\text { 窝 } \\
\text { 腺 }\end{array}$} & \multirow{2}{*}{ 肺 } & \multirow{2}{*}{ 胿 } & \multirow{2}{*}{ 脾 } & \multirow{2}{*}{$\begin{array}{l}\mathrm{g} / \mathrm{g} \text { 白量 } \\
\mathrm{g} / \mathrm{dl}\end{array}$} & \multirow{2}{*}{$\mathrm{A} / \mathrm{G}$} & \multirow{2}{*}{$\mathrm{A} \frac{\mathrm{g} / \mathrm{dl}}{\%}$} & \multicolumn{3}{|c|}{ グロブリン $\frac{\mathrm{g} / \mathrm{dl}}{\%}$} \\
\hline & & & & & & & & & & & & & $\alpha$ & $\beta$ & $r$ \\
\hline 3 & $q$ & 150 & 6 月 & 0.5 & $\infty$ & $\infty$ & -1 & - & + & 5.2 & 0.89 & $\begin{array}{c}2.44 \\
47.0\end{array}$ & $\begin{array}{c}0.53 \\
10.2\end{array}$ & $\begin{array}{l}1.04 \\
23.0\end{array}$ & $\begin{array}{c}1.16 \\
22.4\end{array}$ \\
\hline 8 & $\hat{\delta}$ & 180 & 7 月 & 0.7 & $\infty$ & $\infty$ & -1 & \pm & + & 5.0 & 1.00 & $\begin{array}{r}2.5 \\
50.0\end{array}$ & $\begin{array}{c}0.71 \\
14.5\end{array}$ & $\begin{array}{c}0.05 \\
13.1\end{array}$ & $\begin{array}{c}1.11 \\
22.3\end{array}$ \\
\hline 18 & 우 & 200 & 7 月 & 1.8 & $\infty$ & $\infty$ & - & - & - & 5.0 & 1.20 & $\begin{array}{c}2.75 \\
55.0\end{array}$ & $\begin{array}{c}0.72 \\
13.7\end{array}$ & $\begin{array}{c}0.75 \\
17.0\end{array}$ & $\begin{array}{c}0.72 \\
13.7\end{array}$ \\
\hline 20 & 9 & 250 & 7 月 & 1.2 & $\infty$ & $\infty$ & -1 & -1 & - & 6.0 & 0.66 & $\begin{array}{c}2.71 \\
45.2\end{array}$ & $\begin{array}{c}1.17 \\
18.8\end{array}$ & $\frac{1.26}{21.0}$ & $\begin{array}{r}0.9 \\
15.0\end{array}$ \\
\hline 29 & $q$ & 120 & 10 月 & 1.0 & $\infty$ & $\infty$ & -1 & - & + & 6.0 & 0.78 & $\begin{array}{c}2.56 \\
42.8\end{array}$ & $\begin{array}{c}0.75 \\
12.5\end{array}$ & $\begin{array}{c}0.99 \\
16.6\end{array}$ & $\begin{array}{c}1.67 \\
27.9\end{array}$ \\
\hline 31 & $\delta$ & 180 & 8 月 & 1.5 & $\infty$ & $\infty$ & -1 & -1 & + & 8.8 & 1.13 & $\begin{array}{c}4.64 \\
52.8\end{array}$ & $\begin{array}{l}0.86 \\
9.8\end{array}$ & $\begin{array}{c}1.49 \\
17.0\end{array}$ & $\begin{array}{c}1.72 \\
19.6\end{array}$ \\
\hline 39 & $\hat{o}$ & 170 & 7 月 & 1.8 & H & $\mathrm{H}$ & - & + & + & 6.4 & 0.89 & $\begin{array}{c}3.02 \\
47.2\end{array}$ & $\begin{array}{c}0.70 \\
11.0\end{array}$ & $\begin{array}{l}1.42 \\
22.2\end{array}$ & $\begin{array}{l}1.06 \\
16.6\end{array}$ \\
\hline 40 & 8 & 180 & 10月 & 1.8 & $\infty$ & $\infty$ & - & + & + & 7.0 & 1.26 & $\begin{array}{c}3.90 \\
55.8\end{array}$ & $\begin{array}{c}1.23 \\
17.6\end{array}$ & $\begin{array}{c}1.02 \\
14.7\end{array}$ & $\begin{array}{c}0.77 \\
11.1\end{array}$ \\
\hline 42 & $\delta$ & 200 & 10月 & 1.0 & $\infty$ & $\infty$ & - & - & - & 6.4 & 0.78 & $\begin{array}{c}2.73 \\
42.8\end{array}$ & $\begin{array}{c}0.90 \\
14.2\end{array}$ & $\begin{array}{c}1.52 \\
23.8\end{array}$ & $\begin{array}{c}1.21 \\
19.0\end{array}$ \\
\hline 43 & P & 190 & 10 月 & 1.0 & $\infty$ & $\infty$ & - & - & + & 5.6 & 0.72 & $\begin{array}{c}2.46 \\
44.1\end{array}$ & $\begin{array}{c}0.95 \\
17.0\end{array}$ & $\begin{array}{c}1.14 \\
20.5\end{array}$ & $\begin{array}{c}0.95 \\
17.0\end{array}$ \\
\hline 46 & $q$ & 170 & 10 月 & 0.5 & $\infty$ & $\infty$ & - & -1 & - & 6.4 & 0.80 & $\begin{array}{l}2.68 \\
41.9\end{array}$ & $\begin{array}{c}1.03 \\
16.1\end{array}$ & $\begin{array}{c}1.23 \\
19.3\end{array}$ & $\begin{array}{c}1.44 \\
22.5\end{array}$ \\
\hline 4 & & & 均 & & & & & & & 6.1 & 0.919 & $\begin{array}{l}2.67 \\
47.7\end{array}$ & $\begin{array}{c}0: 866 \\
14.1\end{array}$ & $\begin{array}{c}1.18 \\
18.6\end{array}$ & $\begin{array}{c}1.16 \\
18.8\end{array}$ \\
\hline
\end{tabular}

